\title{
Analisis Masalah Untuk Menentukan Minimasi Waste Pada Proses Produksi di PT. XYZ
}

\author{
Fauziah Amelia Ananda ${ }^{1)}$, Wahyudi Sutopo ${ }^{2)}$ \\ Program Studi Teknik Industri, Fakultas Teknik, Universitas Sebelas Maret \\ Jalan Ir Sutami No.36 A, Surakarta, 57126, Indonesia \\ E-Mail :fauziahamelia@student.uns.ac.id ${ }^{l)}$,wahyudisutopu@staff.uns.ac.id ${ }^{2)}$
}

\begin{abstract}
ABSTRAK
PT. XYZ merupakan salah satu perusahaan manufaktur di Indonesia yang memiliki karakteristik maketo-order dalam proses produksinya. Salah satu produk yang ada di perusahaan tersebut adalah baja slab, yang di mana baja slab ini merupakan komponen utama untuk proses produksi baja selanjutnya. Dari hasil observasi diketahui bahwa perusahaan sering tidak dapat mencapai target produksi dikarenakan adanya pemborosan dalam proses produksi yang berupa cacat dan delay, yang kemudian menambah biaya produksi. Oleh karena itu, minimalisasi waste penting untuk dilakukan. Metode yang digunakan yaitu VSM, dengan FMEA dan $5 \mathrm{~W}+1 \mathrm{H}$ sebagai metode penunjang. Berdasarkan data yang diperoleh, ada empat waste terbesar yang menghambat efisiensi produksi baja slab, yaitu defect, overproduction, waiting, dan unnecessary motion. Dalam penelitian ini digunakan tools yaitu Process Activity Mapping, Quality Filter Mapping, dan Future Value Stream Mapping.
\end{abstract}

Kata kunci: FMEA, VALSAT, VSM, 5W + 1H, 7 Waste

Problem Analysis To Determine Waste Minimization in the Production Process at PT. XYZ

\section{ABSTRACT}

PT. XYZ is one of manufacturing companies in Indonesia that has make-to-order characteristics in the production process. One of the company's products is slab steel, in which it is the main component for the next steel production process. From the observations we note that companies often can not achieve production targets due to waste in the production process in the form of defects and delays which then increase production costs. Therefore, waste minimization is important to do. The method used are VSM, with FMEA and $5 \mathrm{~W}+1 \mathrm{H}$ as supporting methods. Based on the data obtained, there are four types of waste that inhibits the efficiency of slab steel production, which are defect, overproduction, waiting, and unnecessary motion. In this research, tools used are Process Activity Mapping, Quality Filter Mapping, and Future Value Stream Mapping.

Keywords: FMEA, VALSAT, VSM, 5W + 1H, 7 Waste

\section{Pendahuluan}

Kesuksesan sebuah industri dilihat berdasarkan dengan kemenangan perusahaan tersebut pada kompetisi pasar. Banyak faktor yang dapat menghalangi tercapainya kesuksesan sebuah industri, dan salah satu hal penting yaitu konsep sistem yang dianut. Berdasarkan latar belakang tersebut, banyak perusahaan manufaktur melakukan perubahan sistem salah satunya mengadopsi konsep lean. Lean manufacture adalah suatu upaya terus menerus untuk menghilangkan pemborosan (waste) yang terjadi di suatu perusahaan industri dan meningkatkan nilai tambah (value added) produk (barang dan/atau jasa) agar memberikan nilai kepada pelanggan (customer value). Tujuan lean adalah meningkatkan terus-menerus customer value melalui peningkatan terus-menerus rasio antara nilai tambah terhadap waste (the value to waste ratio) (Gasperz, 2011). Pemborosan sendiri dapat diartikan sebagai segala aktivitas manusia yang menyerap sumber daya dalam jumlah tertentu tetapi tidak menghasilkan nilai tambah, seperti kesalahan yang membutuhkan pembetulan, hasil produksi yang tidak diinginkan oleh pengguna, proses atau pengolahan yang tidak perlu, pergerakan 
tenaga kerja yang tidak berguna dan menunggu hasil akhir dari kegiatan-kegiatan sebelumnya (Womack dan Jones, 1996 dalam Formoso et al, 2002). Sehingga, dari penerapan lean manufacturing ini diharapkan biaya produksi lebih rendah, output meningkat, dan lead time produksi lebih pendek (Roger, 2008). Akan tetapi, pada kenyataannya perusahaan sering dihadapkan dengan berbagai macam kendala, salah satunya yaitu tidak tercapainya target produksi yang dikarenakan kualitas produk yang tidak memenuhi standar, meskipun sudah menerapkan lean manufacturing. Hal ini dapat menyebabkan perusahaan sulit untuk memasarkan produknya dan peluang untuk bersaing dengan perusahaan lain tipis. Salah satu tool yang yang sering digunakan untuk menggambarkan masalah dari informasiinformasi berikut adalah Value Stream Mapping (VSM). VSM merupakan powerful tool yang tidak hanya dapat mengidentifikasi inefisiensi proses tetapi juga dapat menjadi panduan dalam melakukan perbaikan (Rother dan Shook, 1999). Pada penelitian ini juga digunakan tools berupa Value Stream Analysis Tools dan Diagram Fishbone untuk dapat melihat masalah lebih rinci. Value Stream Analysis Tools berguna sebagai alat bantu untuk memetakan secara detail aliran nilai (value stream) yang berfokus pada value adding process (Hines dan Rich, 1997). Sedangkan Diagram Fishbone merupakan suatu alat visual untuk mengidentifikasi, mengeksplorasi, dan secara grafik menggambarkan secara detail semua penyebab yang berhubungan dengan suatu permasalahan (Scarvada, 2004).

PT. XYZ merupakan salah satu perusahaan yang bergerak di bidang manufaktur. Perusahaan tersebut memproduksi baja, dan salah satu produknya yang dihasilkan yaitu baja slab. Stasiun kerja baja slab merupakan satu dari 6 (enam) stasiun kerja yang di mana hasil produksinya masih akan diproses lagi ke 2 (dua) stasiun kerja yang terdapat di PT. XYZ. Berdasarkan hasil observasi, proses produksi baja slab masih belum mencapai target produksi, baik dari tingkat kecacatan (non-conformity), hasil (yield), dan biaya produksi yang dikeluarkan.
Hal ini disebabkan oleh banyaknya scrap yang ditemukan pada baja slab dengan penyebab utama yaitu ketidaksesuaian pesanan dengan pengaturan komposisi pada bahan atau grade. Sehingga, tujuan penelitian ini adalah mengidentifikasi dan menganalisis waste yang terjadi, mengetahui penyebab adanya waste yang terjadi, serta memberikan usulan untuk meningkatkan efisiensi produksi.

\section{Metodologi}

Bab ini menjelaskan mengenai jenis data yang digunakan dan metode pengumpulan dan pengolahan data yang digunakan selama penelitian berlangsung.

\subsection{Jenis data yang digunakan}

Jenis data yang digunakan dalam penelitian ini adalah data-data yang sudah disediakan dari perusahaan, antara lain data kinerja operasi pabrik slab baja, data heat report plant 1 , data heat report plant 2 , dan data persentase kecacatan pada non conformity. Selain itu juga dilakukan pengumpulan data melalui wawancara untuk mengetahui penyebab banyaknya waste yang terjadi.

\subsection{Metode pengumpulan dan pengolahan data}

Metode pengumpulan dan pengolahan data yang digunakan dalam penelitian ini terbagi menjadi beberapa tahap. Tahap pertama yaitu melakukan perhitungan rata-rata terhadap data efisiensi kinerja operasi pabrik slab baja, yang di mana data tersebut terbagi menjadi 3 (tiga) data yaitu data non conformity, data yield dan data biaya produksi. Dari perhitungan ratarata pada ketiga data tersebut kemudian diketahui apakah proses produksi baja slab dapat dikatakan efisien atau belum. Tahap kedua yaitu melakukan perhitungan total waktu produksi dengan menggunakan data heat report plant 1 dan data heat report plant 2. Dari total waktu produksi kemudian membuat current value stream mapping (CVSM) dan didapatkan persentase value added activity dan persentase non value added activity. Tahap ketiga yaitu melakukan identifikasi dan pengukuran masalah dan waste menggunakan 7 Waste dan $5 \mathrm{~W}+1 \mathrm{H}$. Data 
didapatkan dari hasil wawancara. Kemudian setelah mengetahui jenis-jenis waste yang ada pada proses produksi maka langkah selanjutnya yaitu melakukan pemilihan tools dengan Value Stream Mapping Tools (VALSAT). Tahap keempat yaitu melakukan pembuatan Process Activity Mapping (PAM) dan Quality Filter Mapping (QFM) yang merupakan tools dari dari VALSAT dengan menggunakan data persentase kecacatan pada non conformity. Data ini pun terbagi 2 (dua) menjadi data down grade dan data reject/scrap, dan masing-masing data terbagi lagi menjadi 3 (tiga) yaitu data pada mesin CCM 1, mesin CCM 2 dan mesin CCM 3. Tahap kelima yaitu membuat analisis penyebab adanya waste dengan menggunakan Diagram Fishbone. Dan tahap yang terakhir yaitu menggunakan analisis dari Diagram Fishbone dan $5 \mathrm{~W}+1 \mathrm{H}$ sebagai dasar untuk membuat rekomendasi perbaikan waste dengan Failure Mode and Effect Analysis (FMEA) dan Future Value Stream Mapping (FVSM).

\section{Hasil dan Pembahasan}

\subsection{Efisiensi Kinerja Operasi Pabrik Slab Baja}

Pada bagian ini disajikan data dan analisis efisiensi kinerja operasi pabrik slab baja. Data kinerja operasi pada proses produksi baja slab terbagi menjadi 3 (tiga) data, yaitu data non conformity, data yield dan data biaya produksi. Data kinerja operasi pabrik slab baja didapatkan dari data historis tahun 2018, yang pada tahun tersebut pabrik slab baja beroperasi di bulan Mei, Juli, Agustus, September, Oktober, November dan Desember.

Contoh perhitungan rata-rata persentase non conformity di tahun 2018:

$$
\begin{aligned}
\bar{X} & =\frac{\text { Total Persentase Non Conformity }}{7} \ldots \ldots . . . \\
& =\frac{66,04+6,29+2,97+288+2,67+254+24]}{7} \\
& =3,97 \%
\end{aligned}
$$

Contoh perhitungan rata-rata persentase yield di tahun 2018:

$\overline{\mathrm{X}}=\frac{\text { Total Persentage Field }}{\mathrm{g}}$

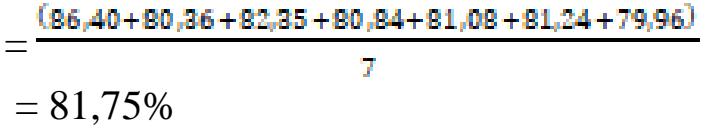

Dari kedua data tersebut, dapat dilihat bahwa selama kegiatan proses produksi baja slab, scrap yang dihasilkan masih banyak dan hasil yang didapatkan masih kurang dari persentase yang ideal, sehingga dapat dikatakan bahwa proses produksi belum efisien. Data biaya produksi terbagi menjadi biaya pencegahan yang terdiri dari gaji dan upah para pekerja tetap dan pengendalian kualitas BLD, biaya penilaian yang terdiri dari gaji dan upah para pekerja outsourcing, reparasi \& perawatan dan pusat perawatan, serta biaya kegagalan intern.

Tabel 1. Perbandingan Biaya

\begin{tabular}{|l|r|r|}
\hline \multicolumn{1}{|c|}{ ITEM } & $\begin{array}{c}\text { JUMLAH } \\
\mathbf{( \$ )}\end{array}$ & $\begin{array}{r}\text { PERSENTASE } \\
(\boldsymbol{\%})\end{array}$ \\
\hline Biaya Pencegahan & & \\
\hline Gaji \& Upah (BBB) & 2250,26 & $68,80 \%$ \\
\hline Pengendalian Kualitas BLD & 1020,70 & $31,20 \%$ \\
\hline Total Biaya Pencegahan & $\mathbf{3 2 7 0 , 9 6}$ & $\mathbf{6 , 8 3 \%}$ \\
\hline Biaya Penilaian & & \\
\hline Gaji \& Upah (BV) & 5879,94 & $28,50 \%$ \\
\hline Reparasi \& Perawatan & 11281,98 & $54,67 \%$ \\
\hline Pusat Perawatan & 3472,74 & $16,83 \%$ \\
\hline Total Biaya Penilaian & $\mathbf{2 0 6 3 4 , 6 6}$ & $\mathbf{4 3 , 0 8 \%}$ \\
\hline Biaya Kegagalan Intern & & \\
\hline Scrap Defect & 23989,40 & $100,00 \%$ \\
\hline Total Biaya Kegagalan Intern & $\mathbf{2 3 9 8 9 , 4 0}$ & $\mathbf{5 0 , 0 9 \%}$ \\
\hline TOTAL BIAYA & $\mathbf{4 7 8 9 5 , 0 2}$ & $\mathbf{1 0 0 , 0 0 \%}$ \\
\hline
\end{tabular}

Contoh perhitungan total biaya penilaian:

Total Biaya Penilaian

$=$ Gaji \& Upah $(\mathrm{BV})+$ Reparasi \& Perawatan

+ Pusat Perawatan

$=\$ 5879,94+\$ 11281,98+\$ 3472,74$

$=20634,66$

Contoh perhitungan persentase pada total biaya pencegahan:

Persentase pada Biaya Pencegahan

$=\frac{\text { Total Biaya Pencegahan }}{\text { Total Biaya Nualitas }} \times 100 \%$

$=\frac{2270,96}{47895,02} \times 100 \%$

$=6,83 \%$ 
Dari tabel di atas, dapat diketahui bahwa biaya yang paling mempengaruhi total biaya kualitas yaitu biaya kegagalan intern sebesar $\$ 23.989,40$ (50,09\%). Biaya ini terjadi karena produk scrap telah terdeteksi sebelum dikirim ke customer. Hal ini menunjukkan proses inspeksi yang dilakukan perusahaan sudah cukup ketat, akan tetapi hal ini juga menandakan bahwa perusahaan kurang memperhatikan hal-hal yang dapat mencegah terjadinya kegagalan produk.

Pada proses produksi baja slab, biaya kegagalan ekstern tidak dapat diidentifikasi dikarenakan baja yang akan dikirim ke customer merupakan baja yang kualitasnya pasti baik untuk diolah lagi di pabrik selanjutnya, yaitu pabrik yang memproduksi hot rolled coil, hot rolled plate, cold rolled sheet dan cold rolled coil. Hal tersebut mengakibatkan unit produksi baja slab tidak menerima keluhan dari customer. Akan tetapi, hasil ini juga menunjukkan bahwa Divisi Produksi perlu melakukan re-check dengan Divisi Marketing sebelum melakukan proses produksi sehingga biaya kegagalan intern dapat ditekan, yang kemudian dapat menekan biaya penilaian, dan keseluruhan total biaya kualitas akan berkurang.

\subsection{Identifikasi Value Stream Dengan Current Value Stream Mapping (CVSM)}

Pada sub bab ini disajikan perhitungan dan analisis identifikasi value stream dengan current value stream mapping (CVSM). Value stream mapping (VSM) merupakan sebuah visualisasi aliran material dan informasi dalam proses produksi. VSM diperlukan sebagai langkah awal dalam proses identifikasi adanya pemborosan (waste) selama proses produksi baja slab.

Contoh perhitungan perbandingan value added time (VA) dan total waktu keseluruhan:

$$
\begin{aligned}
& \text { Persentase }=\frac{\text { walue added time (VA) }}{\text { VA + non walue added time (NVA) }} \\
& =\frac{2355,09}{3255,09+3404, \sqrt{3} 9} \\
& =49,64 \%
\end{aligned}
$$

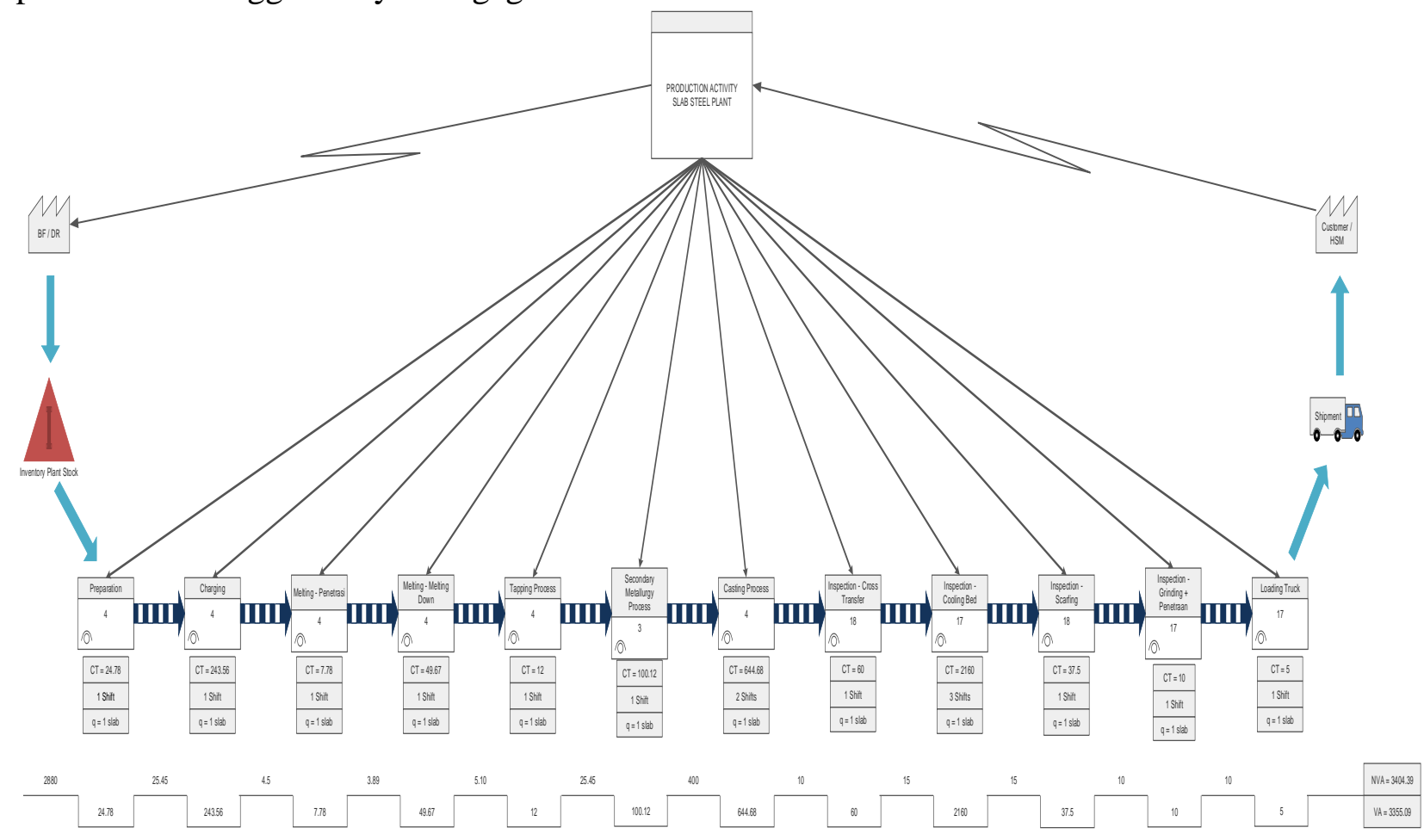

Gambar 1. Current Value Stream Mapping 
Dari perhitungan di atas dapat diketahui bahwa persentase value added time (VA) hanya sebesar $49,64 \%$ dari total waktu keseluruhan yaitu 3355,09 menit dalam proses produksi baja slab, dan persentase non value added time (NVA) sebesar 3404,39 menit. Lamanya proses produksi tersebut dikarenakan waktu tunggu dan waktu inspeksi tidak bisa dipastikan dan berbeda untuk setiap baja slab.

\subsection{Identifikasi Waste dan Masalah} Menggunakan 7 Waste, $5 \mathrm{~W}+1 \mathrm{H}$ dan Diagram Fishbone, Pemilihan Tools Dengan Value Stream Analysis Tools (VALSAT), dan Pembuatan Process Activity Mapping (PAM)

Pada sub bab ini disajikan perhitungan dan analisis identifikasi waste dan masalah menggunakan 7 Waste dan $5 \mathrm{~W}+1 \mathrm{H}$, perhitungan dan analisis pemilihan tools dengan value stream analysis tools (VALSAT), dan perhitungan dan analisis process activity mapping (PAM).

Waste dapat didefinisikan sebagai segala aktivitas kerja yang tidak memberikan nilai tambah dalam proses transformasi input menjadi output sepanjang value stream. Untuk mendapatkan informasi mengenai pemborosan yang terjadi pada proses produksi dilakukan identifikasi pengamatan langsung terhadap proses value stream pembuatan baja slab yang meliputi setiap proses kerja dalam pembuatan baja slab dan setiap stasiun kerja dalam hal ini adalah tempat kerja (lingkungan kerja) sepanjang value stream pembuatan produk, kemudian dari identifikasi pemborosan dilakukan pemberian skor dan pemberian ranking dari setiap pemborosan. Pemberian skor dan ranking untuk setiap pemborosan dilihat berdasarkan tingkat intensitas munculnya pemborosan tersebut. Skor 1 menunjukkan bahwa pemborosan tersebut jarang / hampir tidak pernah terjadi, skor 2 menunjukkan bahwa pemborosan tersebut sesekali terjadi, dan skor 3 menunjukkan bahwa pemborosan tersebut sering / hampir selalu terjadi saat proses produksi sedang berlangsung.

Dari Tabel 2 dapat diketahui bahwa terdapat 4 jenis waste yang menghambat lancarnya proses produksi baja slab. Waste tersebut antara lain defect, over production, waiting dan unnecessary motion. Waste defect banyak ditemukan pada saat proses inspeksi berlangsung, yang diakibatkan oleh salah pengaturan komposisi bahan atau grade yang ditentukan sesuai dengan pesanan, kemudian terdapat beberapa masalah di bagian alatnya, seperti pada tundish yaitu level tundish kurang dari suhu yang ditentukan dan tidak memakai dum \& weir, pada pouring tube terdapat bagian yang patah/bocor/retak, dan pada shroud terjadi proses casting tanpa argon/shroud dan posisi yang gantung/bocor/miring.

Waste over production terjadi karena produksi yang berlebihan, yang juga disebabkan oleh salah pengaturan komposisi bahan atau grade yang ditentukan yang sesuai dengan pesanan dikarenakan pesanan tidak pas dengan kapasitas produksi dan material yang disediakan tidak sesuai dengan target pesanan.

Waste waiting terjadi karena jarak pada beberapa antar proses lumayan jauh sehingga beberapa proses perlu menunggu cukup lama untuk diproses contohnya yaitu pada proses preparation dan proses casting. Selain itu faktor-faktor seperti umur mesin (sparepart obsolete, tundish bocor/tidak bisa dikontrol, terjadinya breakdown), sering terjadinya breakdown pada mesin dan baja cair cepat membeku menyebabkan waktu tunggu proses selanjutnya semakin lama.

Waste unnecessary motion terjadi karena operator masih banyak melakukan gerakan yang tidak perlu, seperti pada proses charging masih banyak ditemukan proses yang dijalankan kemudian dimatikan dalam rentang waktu yang singkat, kemudian juga lupa SOP, salah pencet tombol, kurangnya motivasi kerja, suhu panas dan kebisingan. 
Tabel 2. Identifikasi 7 Pemborosan

\begin{tabular}{|c|c|c|c|c|}
\hline No & Pemborosan & Skor & Rank & Bobot \\
\hline 1 & Over Production & 2 & 2 & $30 \%$ \\
\hline 2 & Defect & 3 & 1 & $40 \%$ \\
\hline 3 & Unnecessary Inventory & 0 & 6 & 0 \\
\hline 4 & Innapropriate Processing & 0 & 6 & 0 \\
\hline 5 & Excessive Transportation & 0 & 6 & 0 \\
\hline 6 & Waiting & 1 & 4 & $15 \%$ \\
\hline 7 & Unnecessary Motion & 1 & 4 & $15 \%$ \\
\hline \multicolumn{2}{|r|}{ Total } & 7 & & $100 \%$ \\
\hline
\end{tabular}

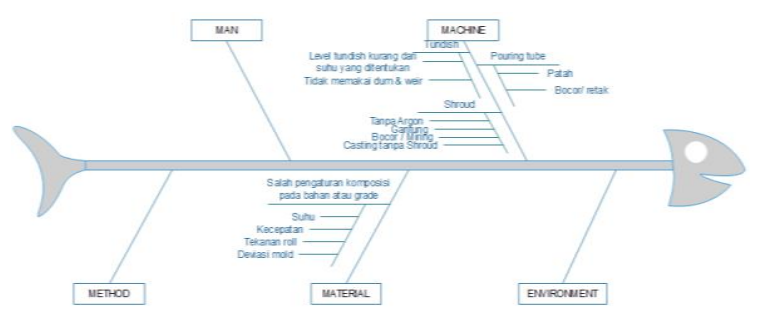

Gambar 2. Diagram Fishbone Defect

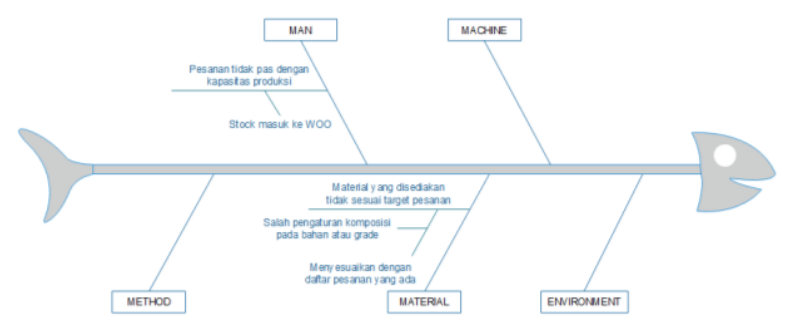

Gambar 3. Diagram Fishbone Over Production

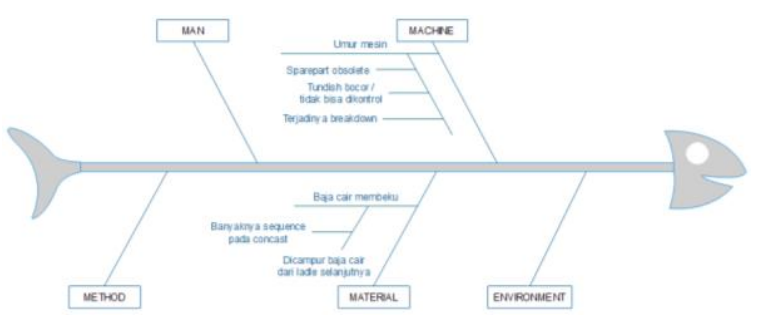

Gambar 4. Diagram Fishbone Waiting

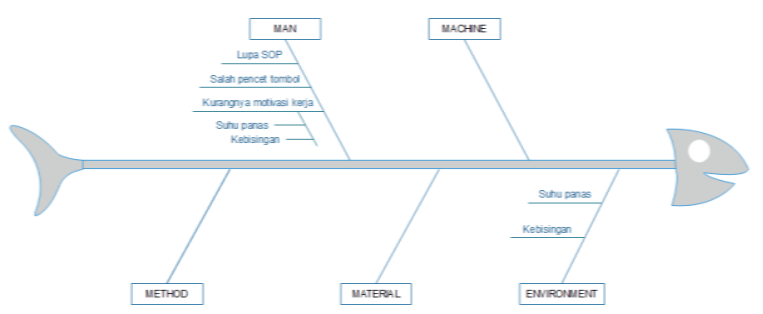

Gambar 5. Diagram Fishbone Unnecessary Motion 
Tabel 3. $5 \mathrm{~W}+1 \mathrm{H}$

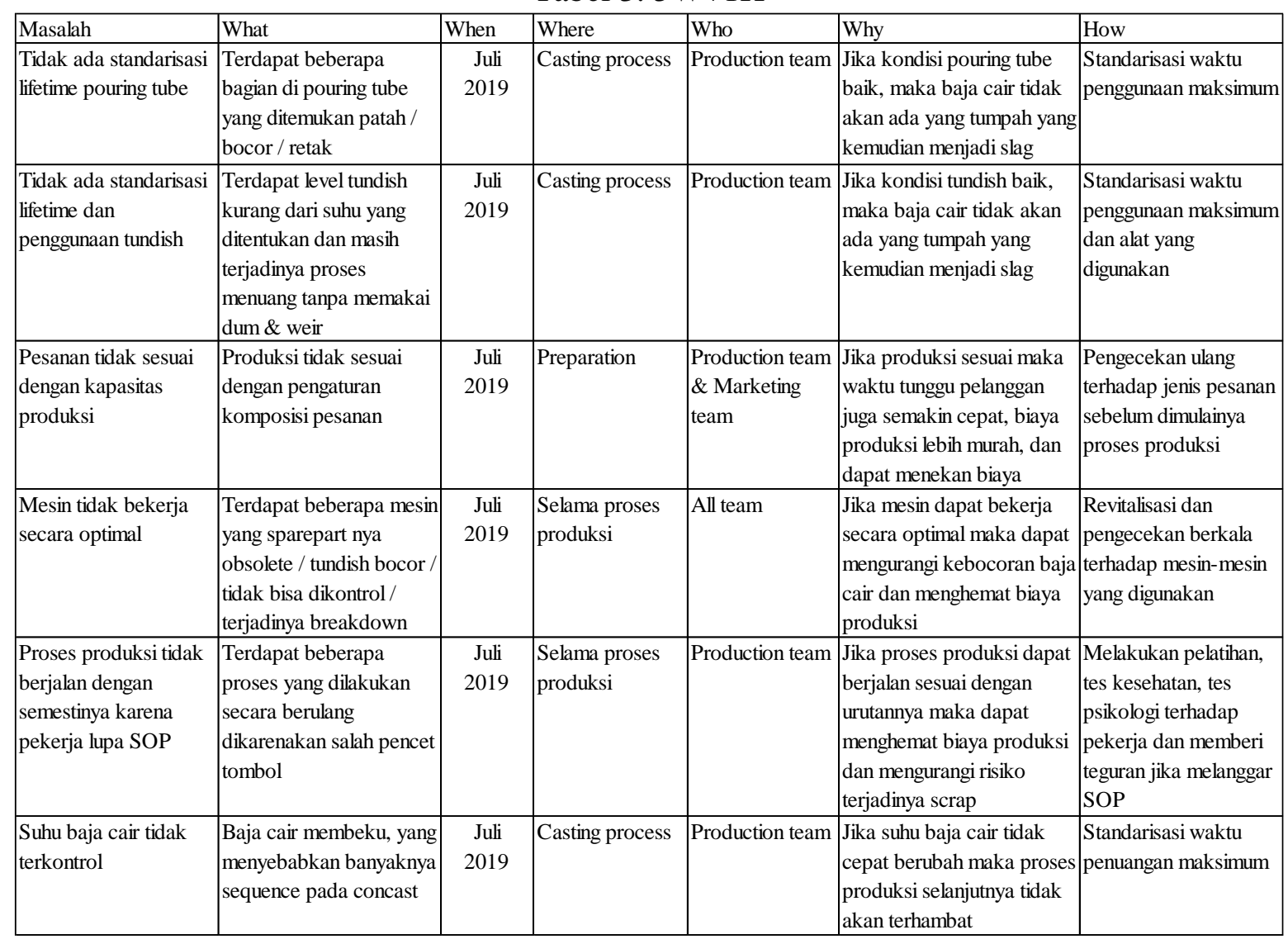

Kemudian dilakukan juga analisis identifikasi masalah menggunakan $5 \mathrm{~W}+1 \mathrm{H}$. Pada analisis ini lebih dijelaskan secara detail beberapa masalah yang sering terjadi selama proses produksi, yaitu tidak ada standarisasi lifetime pouring tube, tidak ada standarisasi lifetime dan penggunaan tundish, pesanan tidak sesuai dengan kapasitas produksi, mesin tidak bekerja secara optimal, proses produksi tidak berjalan dengan semestinya karena pekerja lupa SOP, dan suhu baja cair tidak terkontrol.

Setelah ditentukan jenis waste yang ada pada proses produksi baja slab, langkah selanjutnya yaitu melakukan pemilihan tools dengan value stream analysis tools (VALSAT). Pemilihan tools ini dilakukan untuk memperoleh tools yang dapat secara tepat menggambarkan aliran nilai yang terjadi di lantai produksi perusahaan. Value stream analysis tools ini diperoleh dari hasil perkalian antara rata rata setiap tipe pemborosan hasil identifikasi waste dengan nilai korelasi antara tools dengan waste yang terjadi sehingga diperoleh skor untuk setiap tools yang ada pada VALSAT. Penentuan bobot dan ranking dilihat berdasarkan skor yang ditentukan di 7 Waste dikalikan tingkat intensitas masalah tersebut muncul. Pada penelitian ini, terdapat 3 tingkat seberapa sering masalah muncul (occurrence) dengan penilaian Low (skor 1), Medium (skor 3) dan High (skor 9).

Contoh perhitungan VALSAT sesuai dengan tipe waste:

Tipe waste

$=$ rata-rata waste $\times$ nilai korelasi Defect $(\mathrm{QFM})$

$=3 \times 9$

$=27$

Berdasarkan hasil perhitungan dengan menggunakan tabel VALSAT diperoleh peringkat matriks atau mapping yang bobotnya tertinggi yaitu Process Activity Mapping 
dengan total bobot 23 dan Quality Filter Mapping dengan total bobot 20, dikarenakan kedua tools tersebut mampu menjelaskan lebih lanjut mengenai waste defect yang ada pada proses produksi baja slab, yang kemudian dapat dijadikan acuan untuk mereduksi pemborosan yang ada pada proses produksi baja slab.

Selanjutnya dilakukan pembuatan process activity mapping (PAM). Penggambaran peta ini berguna untuk mengetahui seluruh value stream activity dan berusaha untuk mengurangi aktivitas yang kurang penting dan menyederhanakannya, sehingga dapat mengurang waste. Dalam tool ini, aktivitas dikategorikan ke dalam beberapa tipe, yaitu operation, transportation, inspection, storage, dan delay.

Tabel 4. Hasil Mapping Tools VALSAT

\begin{tabular}{|l|c|c|c|c|c|c|c|c|}
\hline \multirow{2}{*}{ Waste } & \multirow{2}{*}{ Weight } & \multicolumn{7}{|c|}{ Mapping Tools } \\
\cline { 3 - 11 } & & PAM & SCRM & PVF & QFM & DAM & DPA & PS \\
\hline Over Production & 2 & 2 & 6 & & 2 & 6 & 6 & \\
\hline Waiting & 1 & 9 & 9 & 1 & & 3 & 3 & \\
\hline Excessive Transportation & 0 & 0 & & & & & & 0 \\
\hline Innapropriate Processing & 0 & 0 & & 0 & 0 & & 0 & \\
\hline Unnecessary Inventory & 0 & 0 & 0 & 0 & & 0 & 0 & 0 \\
\hline Unnecessary Motion & 1 & 9 & 1 & & & & & \\
\hline Defect & 3 & 3 & & & 18 & & & \\
\hline \multicolumn{2}{|c|}{ Total } & 23 & 16 & 1 & 20 & 9 & 9 & 0 \\
\hline
\end{tabular}

Tabel 5. Hasil Pemilihan Tools VALSAT

\begin{tabular}{|c|l|c|c|}
\hline No & \multicolumn{1}{|c|}{ VALSAT } & Bobot & Ranking \\
\hline 1 & Process Activity Mapping (PAM) & 23 & 1 \\
\hline 2 & Supply Chain Response Matrix (SCRM) & 16 & 3 \\
\hline 3 & Demand Amplification Mapping (DAM) & 9 & 4 \\
\hline 4 & Decision Point Analysis (DPA) & 9 & 4 \\
\hline 5 & Production Variety Funnel (PVF) & 1 & 6 \\
\hline 6 & Quality Filter Mapping (QFM) & 20 & 2 \\
\hline 7 & Physical Structure (PS) & 0 & 7 \\
\hline
\end{tabular}

Tabel 6. Process Activity Mapping

\begin{tabular}{|c|c|c|c|c|c|c|c|c|c|c|c|}
\hline \multirow{2}{*}{ No. } & \multirow{2}{*}{ Step } & \multirow{2}{*}{ Flow } & \multirow{2}{*}{$\begin{array}{l}\text { Machine } \\
\text { / Facility }\end{array}$} & \multirow{2}{*}{\begin{tabular}{|c|} 
Time \\
(minutes)
\end{tabular}} & \multirow{2}{*}{ People } & \multicolumn{5}{|c|}{ Type of Activity } & \multirow{2}{*}{ Comments } \\
\hline & & & & & & Operation & \begin{tabular}{|l|} 
Transport \\
\end{tabular} & Inspect & Store & Delay & \\
\hline 1 & Preparation & $\mathrm{D}$ & EAF & \begin{tabular}{|l|}
24,78 \\
\end{tabular} & \multirow{5}{*}{4} & \begin{tabular}{|l|}
$\mathrm{O}$ \\
\end{tabular} & \begin{tabular}{|l|}
$\mathrm{T}$ \\
\end{tabular} & $\mathrm{I}$ & $\mathrm{S}$ & $\mathrm{D}$ & \multirow{5}{*}{$\begin{array}{l}1 \text { Foreman per shift } \\
1 \text { Technician per } \\
\text { shift } \\
2 \text { Melter per shift }\end{array}$} \\
\hline 2 & Charging & $S$ & EAF & 243,56 & & $\mathrm{O}$ & $\mathrm{T}$ & I & S & $\mathrm{D}$ & \\
\hline 3 & Melting - Penetrasi & $\mathrm{O}$ & EAF & 7,78 & & $\mathrm{O}$ & $\mathrm{T}$ & I & $\mathrm{S}$ & $\mathrm{D}$ & \\
\hline 4 & Melting - Melting Down & $\mathrm{O}$ & EAF & 49,67 & & $\mathrm{O}$ & $\mathrm{T}$ & I & $\mathrm{S}$ & $\mathrm{D}$ & \\
\hline 5 & Tapping Process & $\mathrm{T}$ & EAF & 12 & & $\mathrm{O}$ & $\mathrm{T}$ & $\mathrm{I}$ & $\mathrm{S}$ & $\mathrm{D}$ & \\
\hline 6 & $\begin{array}{l}\text { Secondary Metallurgy } \\
\text { Process }\end{array}$ & $S$ & LF-RH & 100,12 & 3 & $\mathrm{O}$ & $\mathrm{T}$ & I & S & $\mathrm{D}$ & $\begin{array}{l}1 \text { Foreman per shift } \\
2 \text { Operator per shift }\end{array}$ \\
\hline 7 & Casting Process & $\mathrm{O}$ & $\mathrm{CCM}$ & 644,68 & 4 & $\mathrm{O}$ & $\mathrm{T}$ & I & S & $\mathrm{D}$ & $\begin{array}{l}1 \text { Foreman per shift } \\
2 \text { Caster per shift }\end{array}$ \\
\hline 8 & \begin{tabular}{|l|} 
Inspection - Cross \\
Transfer
\end{tabular} & I & QC & 60 & \multirow{5}{*}{$17-18$} & $\mathrm{O}$ & $\mathrm{T}$ & I & S & $\mathrm{D}$ & \multirow{5}{*}{$\begin{array}{l}3 \text { Observer per shift } \\
2 \text { SP/ME Officer } \\
\text { per shift } \\
6 \text { Inspector per shift } \\
2 \text { Foreman per shift } \\
4-5 \text { Outsourcing } \\
\text { Officer per shift }\end{array}$} \\
\hline 9 & Inspection - Cooling Bed & $\mathrm{I}$ & $\mathrm{QC}$ & 2160 & & $\mathrm{O}$ & $\mathrm{T}$ & $\mathrm{I}$ & $S$ & $\mathrm{D}$ & \\
\hline 10 & Inspection - Scarfing & $\mathrm{I}$ & QC & 37,5 & & $\mathrm{O}$ & $\mathrm{T}$ & $\mathrm{I}$ & $\mathrm{S}$ & $\mathrm{D}$ & \\
\hline 11 & $\begin{array}{l}\text { Inspection - Grinding + } \\
\text { Penetraan }\end{array}$ & I & QC & 10 & & $\mathrm{O}$ & $\mathrm{T}$ & I & S & $\mathrm{D}$ & \\
\hline 12 & $\begin{array}{l}\text { Inspection - Loading } \\
\text { Truck }\end{array}$ & $\mathrm{T}$ & QC & 5 & & $\mathrm{O}$ & $\mathrm{T}$ & I & $S$ & $\mathrm{D}$ & \\
\hline \multicolumn{4}{|c|}{ Total } & 3355,09 & $28-29$ & 3 & 2 & 3 & 2 & 2 & \\
\hline \multicolumn{4}{|c|}{ Operations } & 702,13 & 8 & & & & & & \\
\hline \multicolumn{4}{|c|}{ Value Adding } & $20,93 \%$ & $28,07 \%$ & & & & & & \\
\hline
\end{tabular}


Tabel 7. Penjelasan Process Activity Mapping

\begin{tabular}{|c|l|c|c|}
\hline No & \multicolumn{1}{|c|}{ Aktivitas } & Jumlah aktivitas & Total waktu \\
\hline 1 & Operation & 3 & 702,13 \\
\hline 2 & Transportation & 2 & 17 \\
\hline 3 & Inspection & 3 & 107,5 \\
\hline 4 & Storage & 2 & 343,68 \\
\hline 5 & Delay & 2 & 2184,78 \\
\hline \multicolumn{2}{|c|}{ Total } & 12 & 3355,09 \\
\hline
\end{tabular}

Dari tabel 6 dan 7 dapat dilihat bahwa aktivitas operation menghabiskan waktu paling banyak di antara aktivitas lainnya berdasarkan jumlah aktivitas, dan aktivitas delay menghabiskan waktu paling banyak di antara aktivitas lainnya berdasarkan total waktu. Hal tersebut disebabkan oleh beberapa faktor yang diantaranya adalah jarak perpindahan yang jauh, waktu tunggu minimal pada proses cooling bed di proses inspeksi dan waktu persiapan beberapa alat tertentu.

\subsection{Quality Filter Mapping (QFM)}

Pada sub bab ini disajikan perhitungan dan analisis quality filter mapping (QFM). QFM merupakan tools untuk mengidentifikasi adanya masalah kualitas (cacat) yang terjadi sepanjang supply chain. Pada proses produksi baja slab di PT. XYZ, baja slab yang dikirimkan ke unit produksi selanjutnya merupakan baja-baja slab yang sudah melewati proses inspeksi dan mempunyai defect rate sebesar $0 \%$, dikarenakan pada proses produksi selanjutnya, baja slab akan melewati proses

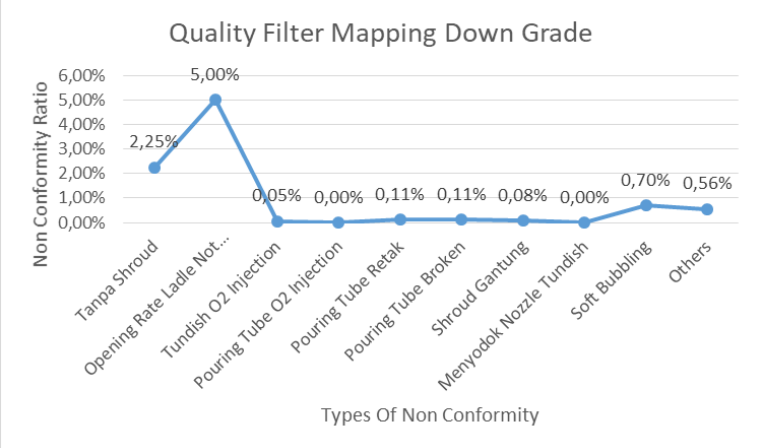

Gambar 2. QFM Down Grade roughing mill yang di mana jika baja slab tersebut ada cacat seperti bolong atau crack maka akan terlihat jelas dan baja slab yang cacat tersebut tidak bisa mengikuti proses selanjutnya. Sehingga pada produksi baja slab ini hanya bisa ditemukan kecacatan berupa non conformity.

Kecacatan non conformity pun terbagi menjadi 2 (dua) jenis, yaitu down grade dan reject/scrap.

Pada jenis down grade, kecacatan yang paling banyak ditemukan disebabkan oleh melakukan proses casting tanpa shroud dan posisi ladle yang tidak sesuai saat menuang baja cair. Hal ini terjadi dikarena umur mesin dan sparepart yang sudah tua dan sering terjadinya breakdown pada mesin.

Pada jenis reject/scrap, kecacatan yang paling banyak ditemukan disebabkan oleh ukuran baja slab yang tidak sesuai (out of length) dan terdapat retakan memanjang (longitudinal crack) pada permukaan baja slab. Hal ini terjadi karena salah pengaturan komposisi pada bahan atau grade.

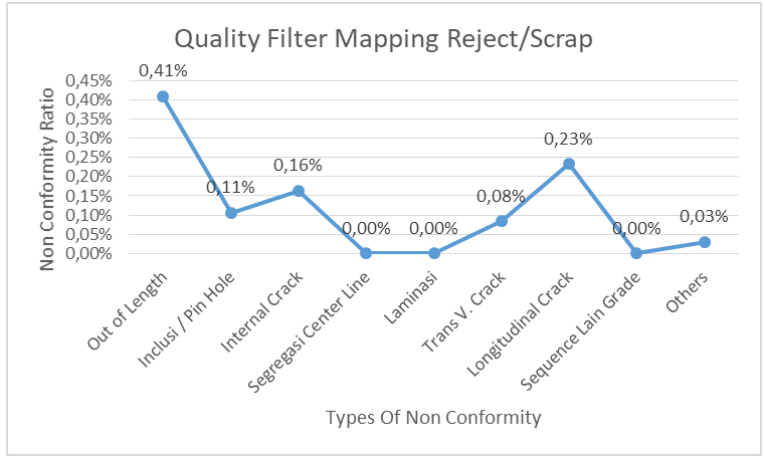

Gambar 3. QFM Reject/Scrap 


\subsection{Diagram Fishbone}

Pada sub bab ini disajikan identifikasi dan analisis diagram fishbone. Diagram fishbone merupakan suatu alat visual untuk mengidentifikasi, mengeksplorasi, dan secara grafik menggambarkan secara detail semua penyebab yang berhubungan dengan suatu permasalahan. Pada proses produksi baja slab terdapat beberapa pemborosan (waste) yang terjadi. Pemborosan (waste) tersebut akan diidentifikasi penyebab dan akibat yang ditimbukan dari sebab tersebut, sehingga mempermudah dalam perbaikan pada proses produksi baja slab.

Penyebab munculnya waste defect yaitu pada tundish terdapat level tundish kurang dari suhu yang ditentukan dan tidak memakai dum \& weir, pada pouring tube terdapat bagian yang patah/bocor/retak, dan pada shroud terjadi proses casting tanpa argon/shroud dan posisi yang gantung/bocor/miring, serta salah pengaturan komposisi pada bahan atau grade.

Penyebab munculnya waste overproduction yaitu pesanan tidak pas dengan kapasitas produksi dan material yang disediakan tidak sesuai dengan target pesanan.

Penyebab munculnya waste waiting adalah umur mesin (sparepart obsolete, tundish bocor/tidak bisa dikontrol, terjadinya breakdown) dan baja cair membeku.

$$
\text { Penyebab munculnya waste }
$$

unnecessary motion adalah lupa SOP, salah pencet tombol, kurangnya motivasi kerja, suhu panas dan kebisingan.

\subsection{Rekomendasi Perbaikan Waste Dengan Failure Mode and Effect Analysis (FMEA)}

Pada sub bab ini disajikan perhitungan dan analisis rekomendasi perbaikan waste dengan failure mode and effect analysis (FMEA) dan future value stream mapping (FVSM).

FMEA digunakan sebagai teknik evaluasi tingkat kehandalan untuk menentukan efek dari kegagalan sistem atau jenis pemborosan.

Dari perhitungan RPN dapat dibuat prioritas dan diharapkan dengan melakukan tindakan perbaikan secara terus-menerus sesuai dengan prioritas yang telah diusulkan, maka pada masa yang akan datang pemborosanpemborosan tersebut bisa dikurangi. Untuk perhitungan RPN diperoleh dari perkalian antara severity $\times$ occurrence $\times$ detection yang diperoleh dari identifikasi langsung pada lantai produksi.

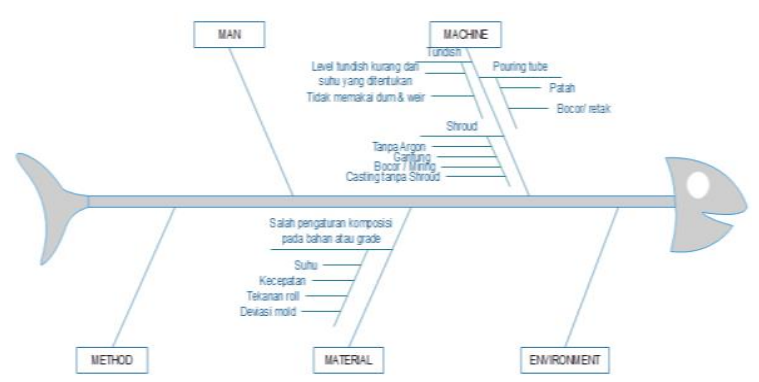

Gambar 4. Diagram Fishbone Defect

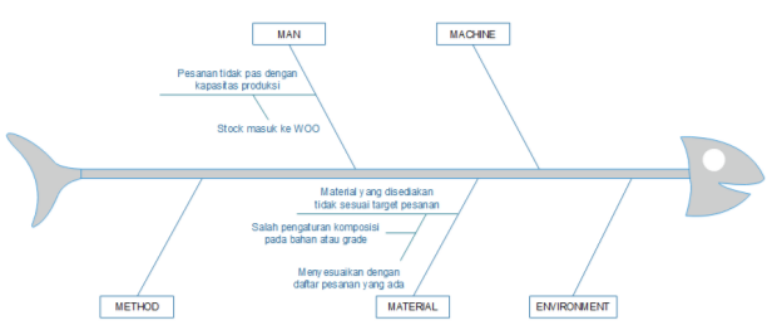

Gambar 5. Diagram Fishbone Over Production

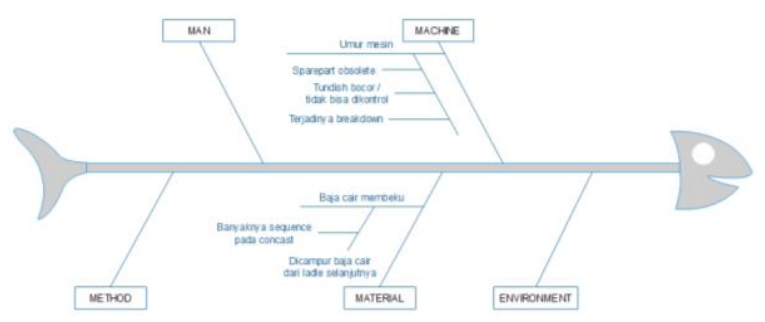

Gambar 6 . Diagram Fishbone Waiting

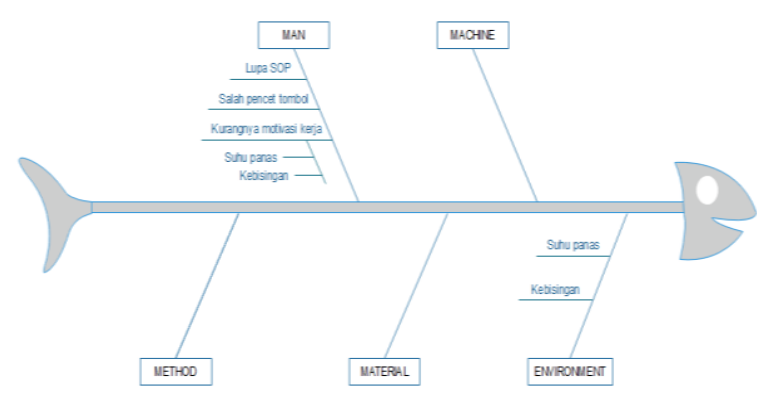

Gambar 7. Diagram Fishbone Unnecessary Motion 
Tabel 7. Failure Mode and Effect Analysis

\begin{tabular}{|c|c|c|c|c|c|c|}
\hline Failure (pemborosan) & Prioritas ke- & $\mathrm{S}$ & $\mathrm{O}$ & $\mathrm{D}$ & RPN & Usulan Perbaikan \\
\hline \multirow[b]{2}{*}{ Defect } & \multirow[b]{2}{*}{1} & \multirow[b]{2}{*}{8} & \multirow[b]{2}{*}{10} & \multirow[b]{2}{*}{1} & \multirow[b]{2}{*}{80} & $\begin{array}{l}\text { Melakukan revitalisasi dan pengecekan berkala } \\
\text { terhadap mesin-mesin yang digunakan }\end{array}$ \\
\hline & & & & & & $\begin{array}{l}\text { Melakukan re-check antara Divisi Marketing } \\
\text { dengan Divisi PPC terkait dengan grade / } \\
\text { spesifikasi yang diinginkan konsumen sebelum } \\
\text { melakukan proses produksi }\end{array}$ \\
\hline Over Production & 2 & 7 & 5 & 2 & 70 & $\begin{array}{l}\text { Melakukan re-check antara Divisi Marketing } \\
\text { dengan Divisi PPC terkait dengan grade / } \\
\text { spesifikasi yang diinginkan konsumen sebelum } \\
\text { melakukan proses produksi }\end{array}$ \\
\hline \multirow[b]{2}{*}{ Waiting } & \multirow[b]{2}{*}{3} & \multirow[b]{2}{*}{1} & \multirow[b]{2}{*}{5} & \multirow[b]{2}{*}{8} & \multirow[b]{2}{*}{40} & $\begin{array}{l}\text { Melakukan revitalisasi dan pengecekan berkala } \\
\text { terhadap mesin-mesin yang digunakan }\end{array}$ \\
\hline & & & & & & $\begin{array}{l}\text { Membuat penjadwalan produksi yang teratur } \\
\text { sesuai dengan grade / spesifikasi yang sesuai } \\
\text { dengan pesanan }\end{array}$ \\
\hline \multirow{2}{*}{ Unnecessary Motion } & \multirow{2}{*}{4} & \multirow{2}{*}{1} & \multirow{2}{*}{4} & \multirow{2}{*}{9} & \multirow{2}{*}{36} & $\begin{array}{l}\text { Melakukan pelatihan yang cukup pada para } \\
\text { tenaga kerja }\end{array}$ \\
\hline & & & & & & $\begin{array}{l}\text { Melakukan tes kesehatan dan tes psikologi } \\
\text { secara berkala pada para tenaga kerja }\end{array}$ \\
\hline Unnecessary Inventory & 5 & 1 & 3 & 10 & 30 & $\begin{array}{l}\text { Melakukan perbaikan jadwal pemesanan bahan } \\
\text { baku }\end{array}$ \\
\hline \multirow{2}{*}{ Innapropriate Processing } & \multirow{2}{*}{6} & \multirow{2}{*}{1} & \multirow{2}{*}{2} & \multirow{2}{*}{10} & \multirow{2}{*}{20} & $\begin{array}{l}\text { Melakukan pelatihan yang cukup pada para } \\
\text { tenaga kerja }\end{array}$ \\
\hline & & & & & & $\begin{array}{l}\text { Melakukan peneguran terhadap tenaga kerja } \\
\text { yang tidak mematuhi SOP dengan baik }\end{array}$ \\
\hline Excessive Transportation & 7 & 1 & 1 & 10 & 10 & $\begin{array}{l}\text { Melakukan pembaharuan alat transportasi untuk } \\
\text { memindahkan barang }\end{array}$ \\
\hline
\end{tabular}

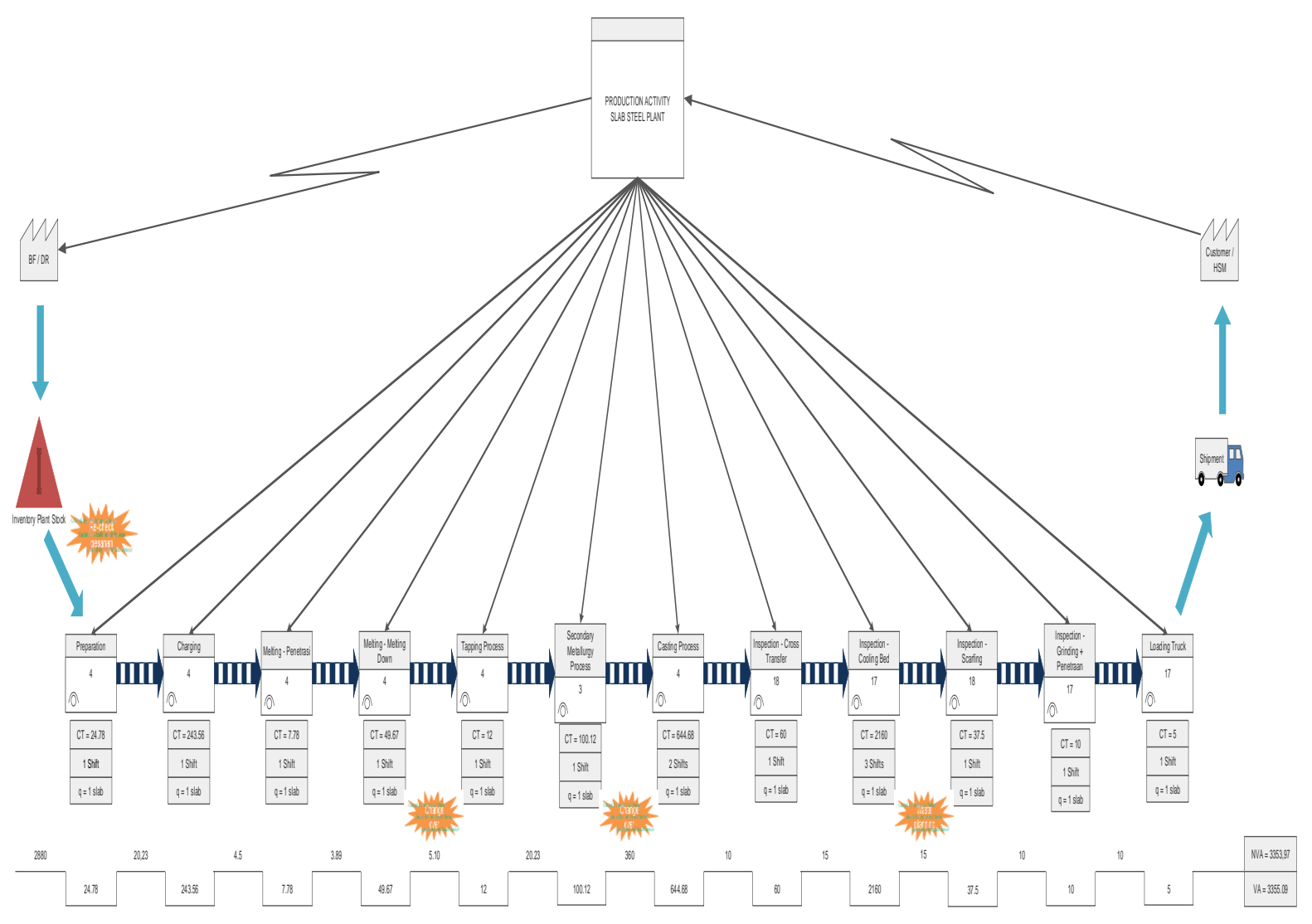

Gambar 8. Future Value Stream Mapping (FVSM) 
Contoh perhitungan RPN:

Defect

$=\mathrm{S} \times \mathrm{O} \times \mathrm{D}$

$=8 \times 10 \times 1$

$=80$

Over Production

$=\mathrm{S} \times \mathrm{O} \times \mathrm{D}$

$=7 \times 5 \times 2$

$=70$

Langkah terakhir yaitu membuat Future Value Stream Mapping (FVSM). FVSM merupakan pemetaan kondisi perusahaan di masa mendatang sebagai usulan rancangan perbaikan dari current state map yang ada (Fariz et al, 2013). Berdasarkan hasil identifikasi waste dan penentuan akar permasalahan dengan menggunakan $5 \mathrm{~W}+1 \mathrm{H}$ kemudian dilakukan perubahan cara kerja pada setiap proses yang mengalami pemborosan karena terjadi pekerjaan berulang serta inventory work in process.

\section{Kesimpulan}

Waste yang teridentifikasi berdasarkan value stream mapping dan fishbone diagram yang terdapat selama proses produksi berlangsung ada 4 (empat) jenis, yaitu defect, over production, waiting dan unnecessary motion.

Berdasarkan hasil perbaikan yang ditemukan dari 5W+1H, Failure Mode and Effect Analysis (FMEA) dan Future Value Stream Mapping (FVSM), didapatkan hasil pengurangan waktu pada kegiatan Preparation ke Charging yang sebelumnya 25,45 menit berubah menjadi 20,23 menit; pada kegiatan Tapping Process ke Secondary Metallurgy Process yang sebelumnya 25,45 menit berubah menjadi 20,23 menit; dan pada kegiatan Secondary Metallurgy Process ke Casting Process yang sebelumnya 400 menit menjadi 360 menit. Pengurangan waktu ini membuat nilai non value added berkurang dari 3404,39 menit menjadi 3353,97 menit, atau berkurang sebanyak $1,48 \%$.
Usulan perbaikan yang dapat dilakukan yaitu dengan melakukan revitalisasi dan pengecekan berkala terhadap mesin-mesin yang digunakan, melakukan re-check antara Divisi Marketing dengan Divisi PPC terkait dengan grade/spesifikasi yang diinginkan konsumen sebelum melakukan proses produksi, membuat penjadwalan produksi yang teratur sesuai dengan grade/spesifikasi yang sesuai dengan pesanan, dan melakukan pelatihan yang cukup pada para tenaga kerja. Selain itu perlu dilakukan standarisasi waktu penggunaan maksimum pada pouring tube, standarisasi waktu penggunaan maksimum dan alat yang digunakan pada tundish, dan standarisasi waktu penuangan maksimum pada baja cair sehingga dapat mengurangi waste yang kemudian dapat mengurangi biaya produksi.

Untuk penelitian selanjutnya dapat mempertimbangkan untuk membuat usulan mengenai standarisasi pada penggunaan alatalat tertentu dan mesin-mesin yang pada proses produksi baja slab.

\section{Daftar Pustaka}

Amrizal, A. (2009). Peningkatan Kualitas dan Efisiensi Layanan Bis Kampus Universitas Indonesia Menggunakan Analisi Value Stream Mapping. Skripsi Fakultas Teknik Universitas Indonesia.

Fernando, Y. (2014). Optimasi Lini Produksi Dengan Value Stream Mapping Dan Value Stream Analysis Tools. Online Journals of Universitas Muhammadiyah Surakarta, 125-133.

Ford Motor Company. (1992). World Wide Potential Failure Mode and Effect Analysis, System - Design - Process Hand Book.

Gasperz, V. (2007). Lean Six Sigma for Manufacturing and Service Industries. Jakarta: PT Gramedia Pustaka Utama.

Harsono R. H. (2010). Usulan Perbaikan Untuk Mengurangi Waste Pada Proses Produksi Dengan Metoda Lean Manufacturing (Studi Kasus di PT PLN (Persero) Jasa dan Produksi, Unit Produksi Bandung). Proceeding Seminar 
Nasional IV Manajemen \& Rekayasa Kualitas, 400-408.

Hidayat, R. (2013). Penerapan Lean Manufacturing Dengan Metode VSM dan FMEA Untuk Mengurangi Waste Pada Produk Plywood. Jurnal Rekayasa \& Manajemen Sistem Industri, 1032-1043.

Hines, P., \& Taylor, D. (2000). Going Lean. Cardiff: Lean Enterprise Research Centre Cardiff Business School.

J. Allen, C. Robinson, \& D. Stewart. (2001). Lean Manufacturing: A Plant Floor Guide. Lexington: Total Systems Development, Inc.

Liker, Jeffery K. (2006). The Toyota Way: 14 Prinsip Manajemen Dari Perusahaan Manufaktur Terhebat di Dunia (diterjemahkan oleh Gina Gania). Jakarta: Penerbit Erlangga.

Mastan, G. J. (2015). Value Stream Mapping: A Case Study of Fastener Industry. IOSR Journal of Mechanical and Civil Engineering (IOSR-JMCE), Vol.12, No.5, 7-10.

Musthofa, S. (2014). Pendekatan Lean Manufacturing Untuk Mereduksi Waste Menggunakan Value Stream Mapping (Studi Kasus Pada PT X Bangil Pasuruan). Brawijaya Knowledge Garden, 337-347.

Osada, T. (2002). Seri Manajemen No. 160: Sikap Kerja 5S. Jakarta: Penerbit PPM.

Prayogo, T. (2013). Identifikasi Waste Dengan Menggunakan Value Stream Mapping Di Gudang PT. XYZ. Publication of Petra Christian University, Vol.1, No.2, 119-126.

Rahani, M. (2012). Production Flow Analysis Through Value Stream Mapping: A Lean Manufacturing Process Case Study. International Symposium on Robotics and Intelligent Sensors 2012 (IRIS 2012), 1727-1734.

Ristyowati, T. (2017). Minimasi Waste Pada Aktivitas Proses Produksi Dengan Konsep Lean Manufacturing (Studi Kasus di PT. Sport Glove Indonesia). Journal Online UPN Veteran Yogyakarta, 85-96.
Roger, A. (2007). Lean Six Sigma Toolkit Lean Overview. Seattle: Expedia Inc.

Rother, M., \& Shook, J. (1999). Learning to See: Value Stream Mapping to Add Value and Eliminate MUDA (foreword by Jim Womack and Dan Jones). Boston: Lean Enterprise Institute.

Soeparman, S. (2013). Minimasi Waste Untuk Perbaikan Proses Produksi Kantong Kemasan Dengan Pendekatan Lean Manufacturing. Journal of Engineering and Management in Industrial System, 8-13.

Utama, D. (2016). Identifikasi Waste Pada Proses Produksi Key Set Clarinet Dengan Pendekatan Lean Manufacturing. Online Journals of Universitas Muhammadiyah Surakarta, 36-46. 